\title{
新しいビームプロセスによるトップダウン加エ 一究極のトップダウン加工を目指して一
}

\author{
寒 川 誠二 \\ 東北大学・流体科学研究所・流体融合研究センター 正 980-8577 宮城県仙台市青葉区片平 2-1-1 \\ (2004 年 3 月 2 日受理)
}

\section{Advanced Beam Processes for Precise Top-down Patterning}

\author{
Seiji SamuKawa \\ Institute of Fluid Science, Tohoku University \\ 2-1-1 Katahira, Aoba-ku, Sendai, Miyagi 980-8577
}

(Received March 2, 2004)

\begin{abstract}
Recent ultra-large-scale integration (ULSI) production processes involve fabricating sub-0.1- $\mu \mathrm{m}$ patterns on $\mathrm{Si}$ wafers. High-density plasma sources are key technologies for developing precise etching processes. The disadvantages of these technologies include several types of radiation damage caused by the charge build-up of positive ions and electrons or by ultraviolet and X-ray photons during etching. These are very serious problems that must be overcome in the fabrication of future nanoscale devices. To overcome these problems and achieve accurate nanoscale patterning, a high-performance neutral-beam etching system is required.
\end{abstract}

\section{1. 序}

論

半導体デバイス製造においては微細加工，表面改質， 薄膜堆積などのキープロセスで反応性プラズマが多く用 いられており，今や原子層レベルの加工精度や堆積精度 が要求されている。しかしながら, 今後の主流となるナ ノオーダーの極微細デバイスにおいては, Fig. 1 (a) に 示すようにプラズマから放射される電子やイオンによる 電荷蓄積や真空紫外光などの放射光による欠陷生成など のデバイス特性を劣化させるダメージがより深刻な問題 になってくる1 10)。ナノデバイスではわずかな欠陥でも 大きくデバイス特性を左右するためである。これらの問 題を解決する手段として, Fig. 1（b）に示すような中性 粒子ビーム技術が注目を集めている11 13)。中性粒子ビ 一ムは荷電粒子や放射光の基板への入射を抑制し，運動 エネルギーを持った中性粒子のみを照射できるので，ダ メージフリーの高精度プロセスが可能であるとして期待 されている。現在まで，プラズマを利用したもの，熱工
ネルギーを利用したものなど多数の中性粒子ビームによ るエッチング加工が報告されている。しかし，これらの 中性粒子ビームではビーム密度が低く, またビームエネ ルギーが大きすぎる (プラズマを利用した場合)，ある いは低すぎる（熱エネルギーを利用した場合）という問 題点があり，プロセスが限定される，あるいは実用性に 乏しいという大きな問題を抱えていた。最近，これらの 問題点を解決できる新しい中性粒子ビーム源が開発さ れ, 実用化が現実的になってきた。現在既に, 最先端シ リコンデバイスの製造において $2 \mathrm{~nm}$ 程度シリコン酸化 膜が用いられており，原子層レベルの表面反応，欠陥生 成などの制御が必要になってきていることから，いよい よ実用的な中性粒子ビームの出番である。本稿では，プ ラズマプロセスにおける深刻な問題, 従来提案された中 性粒子ビーム, そしてそれらの問題を解決するために私 ぞもが開発した新しい中性粒子ビーム生成手法を紹介 し，最近精力的に行われているナノプロセスへの応用に ついて述べる。 
Conventional Etching Process
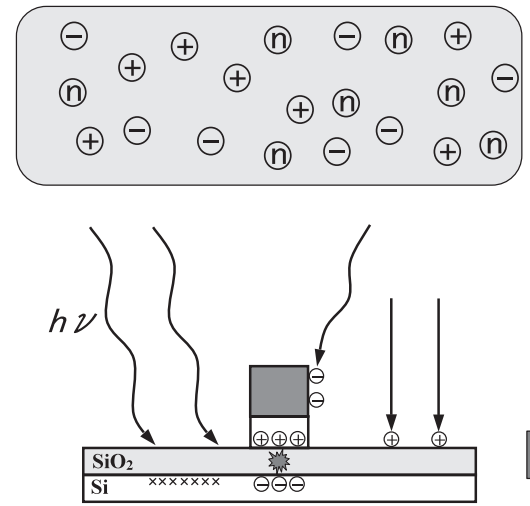

- Damage by Charge Build-up

- Damage by VUV-rays Radiation

(a)
Neutral Beam Etching Process

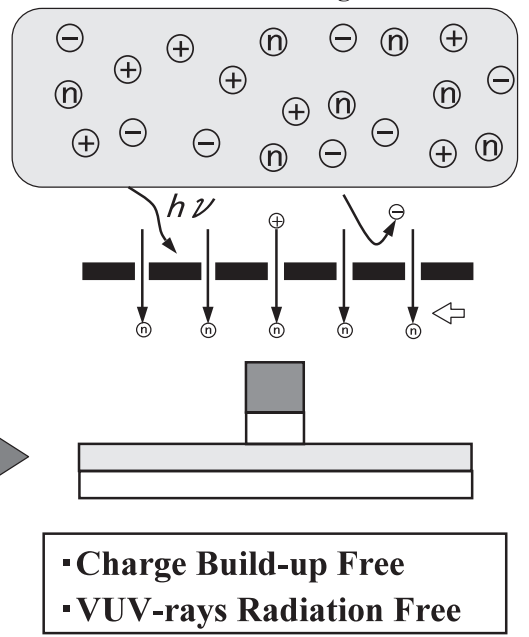

(b)

Fig. 1. Advantages of neutral beam etching in comparison with conventional plasma etching.

Table 1. Comparison of high energy particles in semiconductor fabrication technology.

\begin{tabular}{lllcl}
\hline \multicolumn{1}{c}{ Process } & High Energy Particle & Energy $(\mathrm{eV})$ & Radiation Flux $\left(\mathrm{cm}^{-2}\right)$ & \multicolumn{1}{c}{ Damages } \\
\hline Ion Implantation & Ion & A few $10 \mathrm{k}$ & $10^{10} \sim 10^{16}$ & $\begin{array}{l}\text { Defect } \\
\text { Dislocation } \\
\text { Degradation of Dielectric Film }\end{array}$ \\
& & & & Interface State \\
EB Lithograpy & Electron & A few $10 \mathrm{k}$ & $10^{13}$ & Fixed Charge \\
\hline \multirow{2}{*}{ Plasma Etching } & Ion & $20 \sim 1000$ & $10^{18 \sim 10^{19}}$ & Amorphous \\
& Fast Neutral Atom & $20 \sim 1000$ & $10^{18} \sim 10^{19}$ & $\begin{array}{l}\text { Contamination } \\
\text { Defect } \\
\end{array}$ \\
& Electron & $<50$ & $10^{18} \sim 10^{19}$ & Interface State \\
& Photon (UV) & $>5$ & $10^{14} \sim 10^{15}$ & Degradation of Dielectric Film \\
\hline
\end{tabular}

\section{2. プラズマプロセスの課題}

超 LSI における配線が $100 \mathrm{~nm}$ を切る時代になり，プ ラズマから放射される電荷（イオン, 電子）や光（紫外 線）が加工特性やデバイス特性を大きく劣化させること が問題となっている。Table 1 にプラズマプロセスと高 エネルギー粒子を用いる他の半導体プロセスとを, 入射 粒子種, エネルギー, 照射量, 発生する損傷の種類につ いて比較してある14)。イオン打ち込みや電子ビーム描画 に比べて，プラズマプロセスは入射粒子のエネルギーは 比較的小さいが, 照射量は $10^{19} \mathrm{~cm}^{-2}$ と著しく大きいの が特徵である。このため, 基板表面に多量の損傷が発生 する。

基板表面の微細パターンに蓄積する電荷は, パターン 内へのイオンの入射を妨げてエッチング精度を劣化さ せ, また, ゲート絶縁膜の破壊などデバイス特性を大幅 に低下させている。Fig. 2 にそのメカニズムを示す。基
板表面には電子が先に到達することによって生成される イオンシースがある。このイオンシースでは正イオンは 加速され異方性をもつ。一方, 電子は減速されて熱運動 となるため, 電子はアスペクト比の高いパターン底部に 到達することは難しい。そのため, パターン内では荷電 分離が生じ, 底部に多量の正電荷蓄積がおこる。その結 果として, 下地ゲート絶縁膜が破壊される。また, その 正電荷により入射するイオンの起動が曲げられ, エッチ ングが途中で止まったり (エッチングストップ), 寸法 シフトの大きなエッチングになるなどの問題が指摘され ている。

プラズマから放射される紫外光も絶縁膜中や界面に欠 陥を生じさせるため大きな問題になっている。光子は電 荷を持たず運動量も小さいため純粋なエネルギー供給粒 子と考えられる。紫外線光子のエネルギーが $\mathrm{SiO}_{2}$ バン ドギャップエネルギー $(8.8 \mathrm{eV})$ より大きくなると（紫 外線波長としては $140 \mathrm{~nm}$ 程度以下になると), $\mathrm{SiO}_{2} / \mathrm{Si}$ 

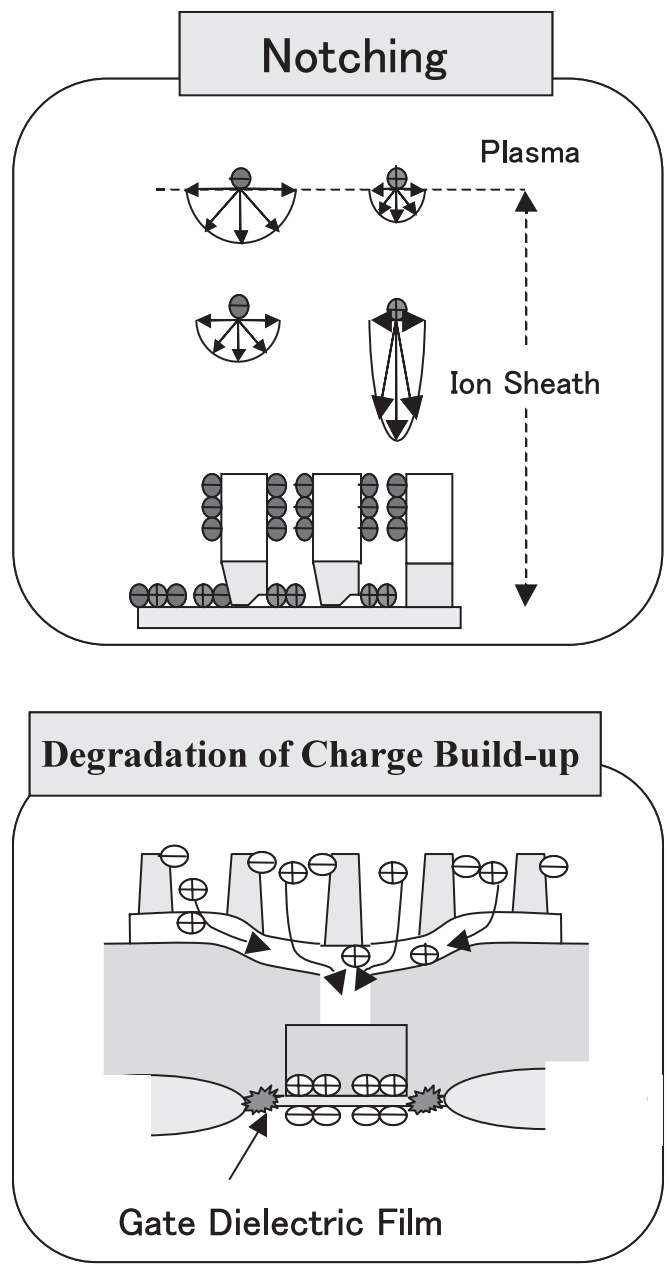

Fig. 2. Charge build-up problems in conventional plasma etching processes.

界面に正電荷が形成されることがわかっている。その形 成率は $10^{-3} \sim 10^{-2}$ の程度である。紫外光によって界面 に正電荷が形成される機構は, 紫外光の吸収によって $\mathrm{SiO}_{2}$ 内に電子-正孔対が形成され, 再結合を免れた正孔 が $\mathrm{SiO}_{2} / \mathrm{Si}$ 界面に到達して捕獲され正電荷が形成される と考えられる。絶緣膜として $\mathrm{Si}_{3} \mathrm{~N}_{4}$ を使う場合にはバン ドギャップが $5 \mathrm{eV}$ 程度であるので, $250 \mathrm{~nm}$ 程度の紫外 光放射まで問題となってくる。これらの紫外光は現在使 われているプラズマ生成条件においては十分に基板に放 射されており，無視することはできない。実際に界面準 位にきわめて敏感である固体撮像素子 (CCD, CMOS イメージセンサー）では，紫外光照射による界面準位上 昇が画像劣化を引き起こし大きな問題となっている。ま た，これら紫外光は表面に欠陥を作ることで表面反応に も大きく寄与している。つまり, 紫外光による欠陥生成 によりエッチング反応を促進するため選択性を劣化させ る, あるいは薄膜堆積においては膜質を劣化させるとい う問題を引き起こしているものと推測される。そのため,

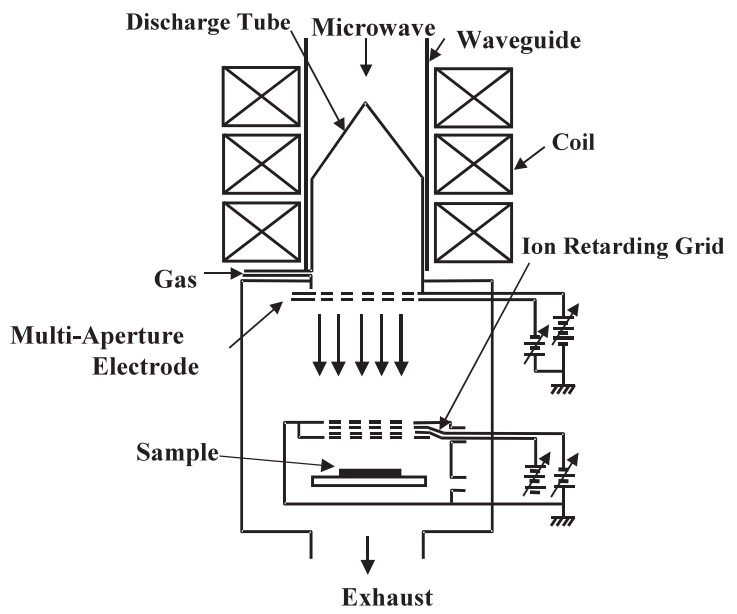

Fig. 3. Conventional neutral beam etching system.

原子層レベルの加工や表面処理を行う場合には，放射光 の抑制制御が極めて重要である。さらに，紫外光照射に 弱い生体超分子や有機分子, カーボンナノチューブなど の新しい物質を用いたデバイスにおける加工・堆積にも 放射光の制御が重要であると考えられる。

このように，今後の革新的先端デバイスで求められる 原子層レベルの加工・堆積プロセスには電荷や光の影響 を抑えた中性粒子ビームが極めて重要な技術になってく ると考えられる。

\section{3. 中性粒子ビーム生成装置}

中性粒子ビームエッチング装置は, 1988 年に日立中 央研究所の水谷ら ${ }^{11}$ や鈴木ら $\left.{ }^{12}\right)$ にって提案された。水 谷らによって提案された中性粒子ビームは Fig. 3 に示す ように，プラズマから正イオンを加速し，途中でガス分 子と衝突させることで運動エネルギー (数百 $\mathrm{eV}$ 以上) を保ったまま電荷交換により中性化された中性粒子ビー 厶を基板に照射するというものである。一方，鈴木らは プラズマを用いるのではなく熱エネルギー $(1 \mathrm{eV}$ 以下 $)$ 程度しかエネルギーを持たないホット分子ビームを提案 した。このホット分子ビームは振動および並進エネルギ 一の励起されたハロゲン系分子ビームである。しかし， これらはそれぞれ大きな問題を抱えていた。水谷らの提 案した中性粒子ビームは正イオンを加速してガス分子と の電荷交換により中性化する方法が取られてきたが，こ の電荷交換を行うには数百 $\mathrm{eV}$ 以上のイオン加速エネル ギーが必要であるばかりでなく, 中性化効率もそれほど 大きくはない。そのため結果として, 低ビーム密度, 高 ビームエネルギーという問題点があり, エッチング速度 が低い，あるいはエッチング選択性が低く実用性にそし かった。鈴木らの提案したホット分子ビームは損傷が極 めて小さいというメリットがあるものの, プラズマエッ 


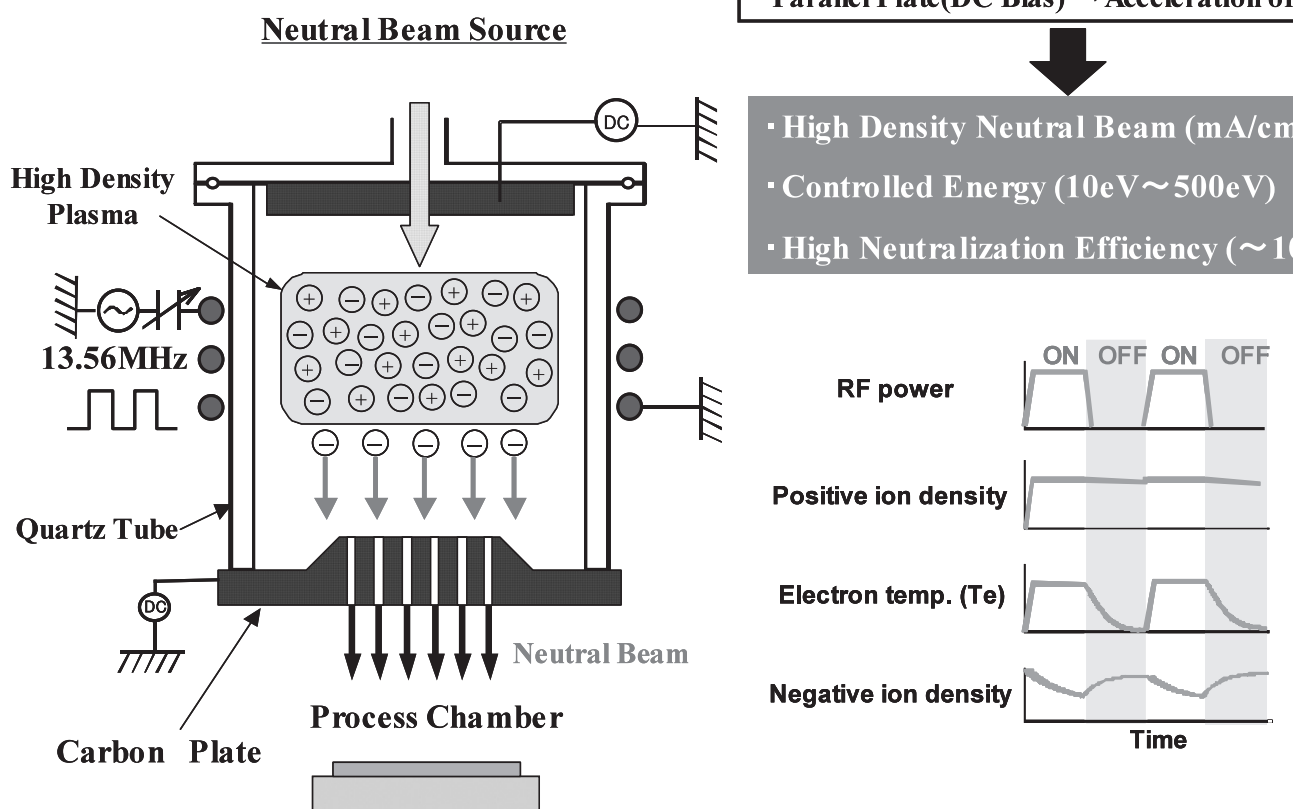

Fig. 4. Our newly developed neutral beam etching system.

チングの数百分の一という低エッチング速度であり, ま た，大面積化も難しいという大きな課題を抱えていた。

そこで，私どもは主に負イオンを中性化する方法を用 いて中性粒子ビームを生成する方法を検討した。負イオ ンは正イオンに比べると弱いエネルギーで電子を離脱さ せることが容易であり, 低エネルギーで高効率な中性粒 子ビーム生成を実現できた。Fig. 4 に私どもが開発した 中性粒子ビーム生成装置の概要を示す15)。基本的に通常 の誘導結合プラズマ源であり, その石英チェンバの上下 にイオン加速用のカーボン電極が設置されている。

この平行平板電極に印加する直流電圧の極性により, 正イオンあるいは負イオンを加速することができる。プ ラズマ放電としては連続放電およびパルス変調放電を用 いることができるが，本装置では主に負イオンを用いて 中性粒子ビームを生成させるために $\mu$ 秒オーダーパル ス変調プラズマを用いた。ガスは上部電極からシャワー 状に導入され，プラズマから加速されたイオンは下部電 極に形成された径 $1 \mathrm{~mm}$ で厚さ $10 \mathrm{~mm}$ のアパーチャー を通過する過程で中性化される。Fig. 5 は $\mathrm{SF}_{6}$ パルス変 調プラズマ（パルス ON 時間： $50 \mu$ 秒，パルス $\mathrm{OFF}$ 時 間： $50 \mu$ 秒）において生成された正負イオンを質量分 析装置で測定した結果である。正イオンとしては $\mathrm{SF}_{3}{ }^{+}$, $\mathrm{SF}_{2}{ }^{+}, \mathrm{SF}^{+}, \mathrm{S}^{+}$などが観察され, 負イオンとしては $\mathrm{F}^{-}$ だけがはっきりと観察された。この時, 正イオンおよび 負イオンを加速し，下部電極アパーチャーを介した中性 粒子ビームの中性化率をそれぞれカロリーメータを使っ
て測定した結果を Fig. 6 に示した。正バイアスを上部電 極に印加し下部電極は接地した場合には正イオンが加速 され，中性化率は精々 50〜 60\% であるが，負バイアス を印加した場合には $90 \%$ 近い中性化率を示している。 負イオンを用いることにより低エネルギー高効率 $\mathrm{F}$ 原 子中性粒子ビーム生成が実現できた。このようにパルス 変調プラズマを用いることでより効率の良い中性粒子ビ 一ムの生成が可能となり，本稿では $\mathrm{F}$ および $\mathrm{Cl}$ 原子ビ 一ムを用いた極微細ゲート電極加工，量子ナノドット形 成や $\mathrm{N}_{2}$ 分子ビームを用いた超高精度な極薄ゲート酸窒 化膜形成技術に関して紹介する。

\section{4. 極微細ゲート電極エッチングへの応用}

Fig. 7 に $\mathrm{SF}_{6} / \mathrm{Cl}_{2}$ 混合ガスプラズマにより形成された $\mathrm{F} / \mathrm{Cl}$ 混合原子ビームにより加工した $50 \mathrm{~nm}$ レベルのポ リシリコンゲート電極エッチング形状を示す16)。加工精 度を高めるためにエッチング速度を $300 \mathrm{~A} / \mathrm{min}$ 程度に 抑え，ビームエネルギーの制御により下地ゲート酸化膜 に対しては 100 程度の選択性が得られている。このとき 注目すべきはレジストに対する選択性も高く単層レジス トでエッチング加工を実現できることである。通常のプ ラズマエッチングを用いた場合には紫外光などの照射に よりレジストが硬化し，プロセス中に倒れたりするため にシリコン酸化膜のようなハードマスクが用いられる。 中性粒子ビームは紫外光放射が抑制されているためにハ ードマスクは必要なく, その結果, よりシンプルで高精 


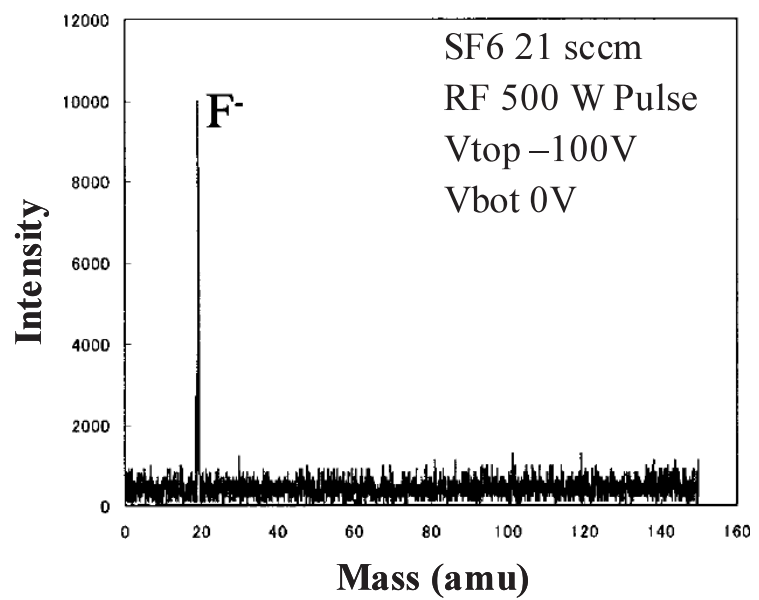

(a)

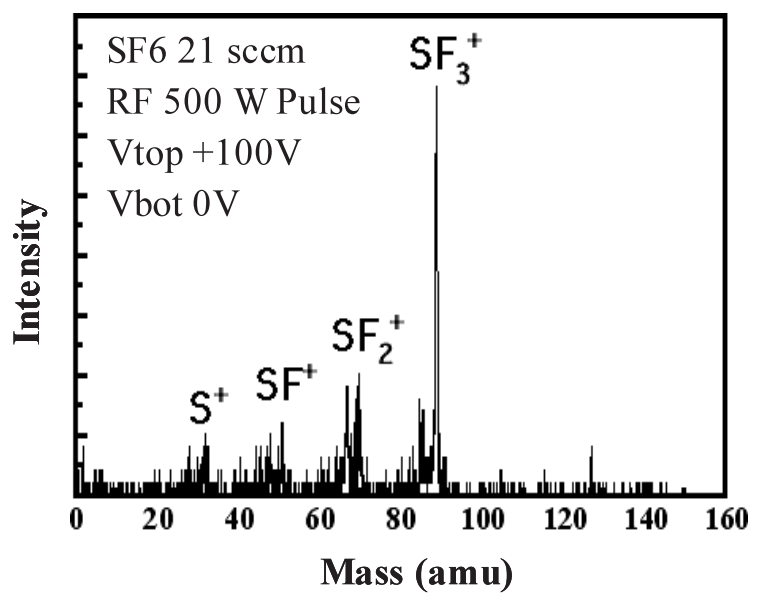

(b)

Fig. 5. Residual ion species by (a) negative DC bias and (b) positive $\mathrm{DC}$ bias in neutral beam ( $\mathrm{SF}_{6}$ plasma).

度な加工が達成されている。このときにゲート酸化膜に 対するダメージについてもアンテナMOS キャパシタ （アンテナ比：400〜20000）を用いて検討を行った。Fig. 8 に照射後のゲート酸化膜リーク電流を通常の高密度プ ラズマによるエッチングと比較した結果を示す。MOS キャパシタにプラズマおよびビームを照射し，その時の ゲートリーク電流を測定した。この結果より中性粒子ビ 一ムを用いたエッチングではアンテナ比依存性は若干あ るものの低電界側のリーク電流がプラズマエッチングの 場合に比べて一桁小さいことがわかった。電荷蓄積や紫 外光放射の抑制により，よりダメージの少ないエッチン グが実現されていることが実証された。このことは次世 代ゲート絶縁膜を選択する上でも極めて重要なデータで ある。このプラズマ照射によるダメージを私どもが開発 したセンサーにて定量的に測定した。Fig. 9 に示すよう に，シリコン酸化膜にプラズマおよび中性粒子ビームを 照射し，シリコン酸化膜中に生成されるホール電流の測

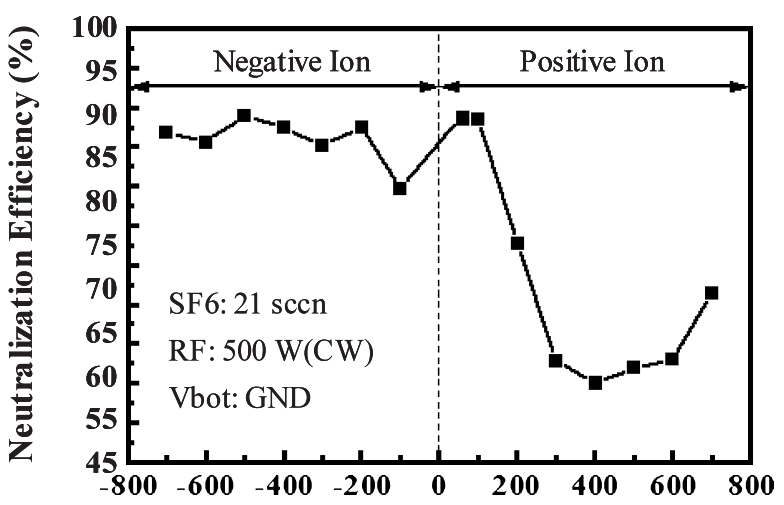

Bias Voltage of Top Electrode Vtop (V)

Fig. 6. Neutralization efficiency of negative ions and positive ions in neutral beam ( $\mathrm{SF}_{6}$ plasma).

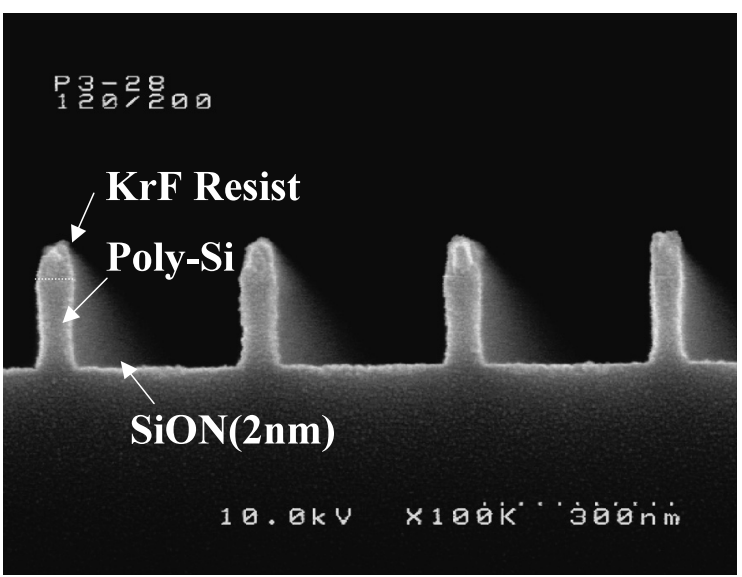

Fig. 7. High-performance $50 \mathrm{~nm}$ poly-Si etching profile using Low energy $\mathrm{Cl} / \mathrm{F}$ neutral beam. $\mathrm{KrF}$ resist was used as the etching mask.

定を行った。この結果は $\mathrm{SiO}_{2} / \mathrm{Si}$ 界面に生成される界面 準位に対応していることは既にわかっており ${ }^{17)}$ ，この結 果からプラズマに比較して中性粒子ビーム照射では殆ど シリコン酸化膜中でホールの生成がないことがわかっ た。このように中性粒子ビームでは従来のプラズマで問 題になる照射損傷を極限まで抑制することが可能である ことがわかり，高誘電率ゲート絶縁膜の実用化段階にお けるプロセス技術として今後，必要不可欠になると考え られる。

\section{5. 極薄ゲート酸窒化膜形成への応用（表面 改質）}

現在，ゲート絶縁膜のリーク電流の低減(高誘電率化) やゲート電極からのボロン付きぬけを防止するねらいで $2 \mathrm{~nm}$ 以下のシリコン酸化膜中に窒素を導入するプラズ マ窒化が注目を集めている。しかしながら，シリコン酸 
Antenna MOS Capacitor(Tox: 5nm)

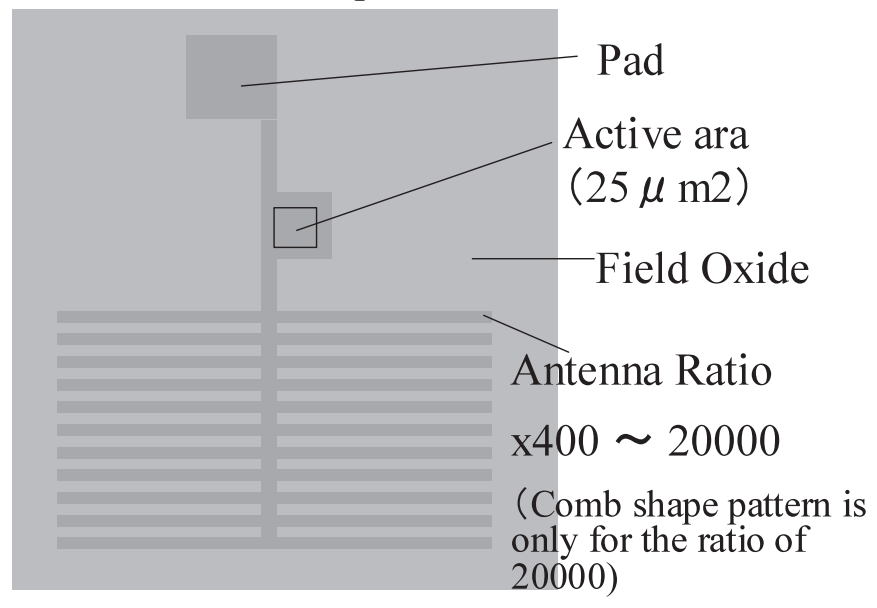

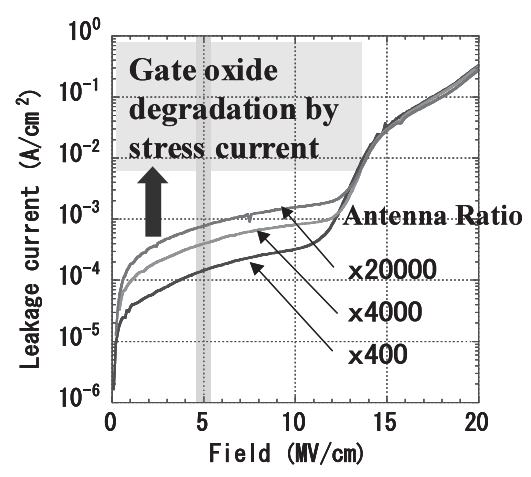

ICP Etching System

(HBr/Cl2 Optimum Condition)

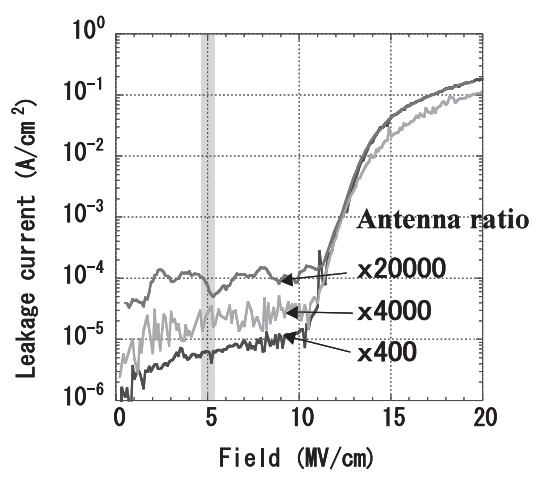

Neutral Beam Etching

(Cl2/SF6 RF bias Optimum Condition)

Fig. 8. Gate oxide leakage current after plasma and neutral beam etchings.

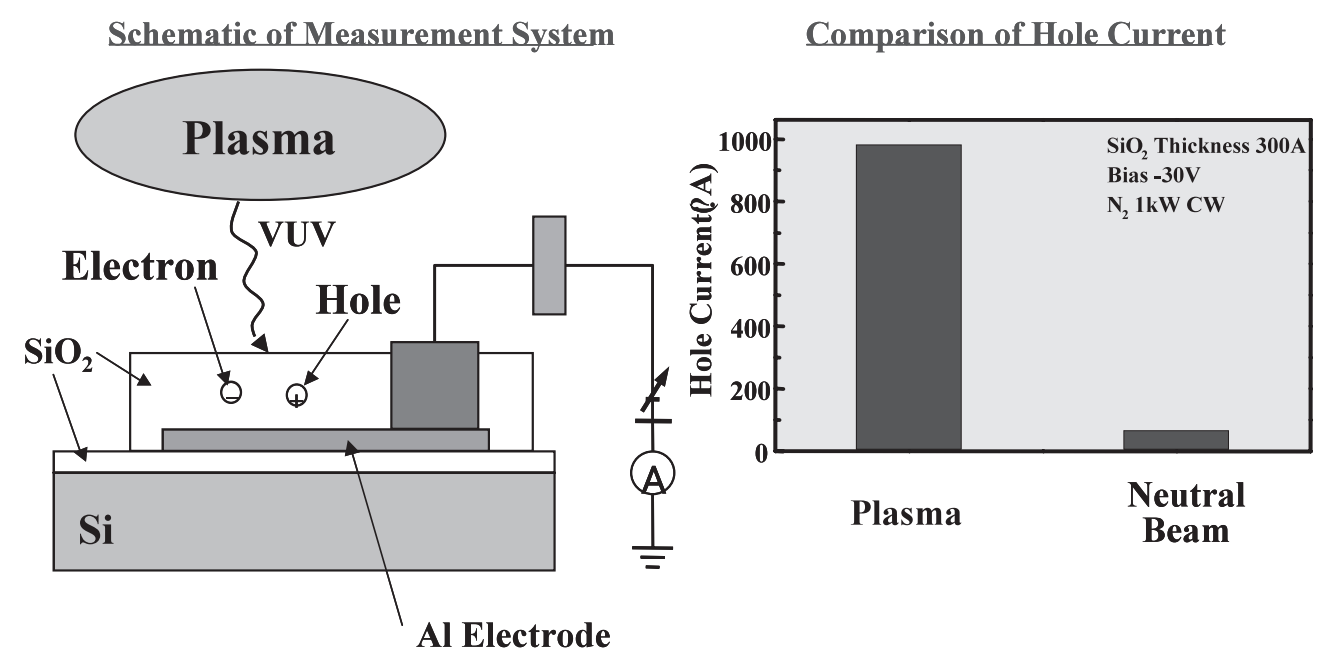

Fig. 9. On-wafer monitoring for measuring UV induced current (hole-electron pair) in $\mathrm{SiO}_{2}$ film. Comparison between plasma radiation and neutral beam radiation. 
化膜中の窒素濃度プロファイルの制御が難しく, 特にシ リコンとの界面に窒素が到達すると界面順位が発生して 信頼性が低下することが問題となっている。また, プラ ズマからの電荷や放射光の照射は欠陥を生成し, やはり デバイス特性を劣化させる原因となる。そこで, 私ども は中性空素分子ビームによるシリコン酸窒化膜の形成を 試みた ${ }^{18)}$ 。窒素プラズマ中では $\mathrm{N}_{2}{ }^{+}$イオンの生成が主で あり, 負イオンの生成はない。この時 $50 \mathrm{eV}$ 以下のビー ムエネルギーでは $\mathrm{N}_{2}+$ イオンの中性化率は $90 \%$ 以上と なっている。Fig. 10 に照射空素中性粒子ビームのピー

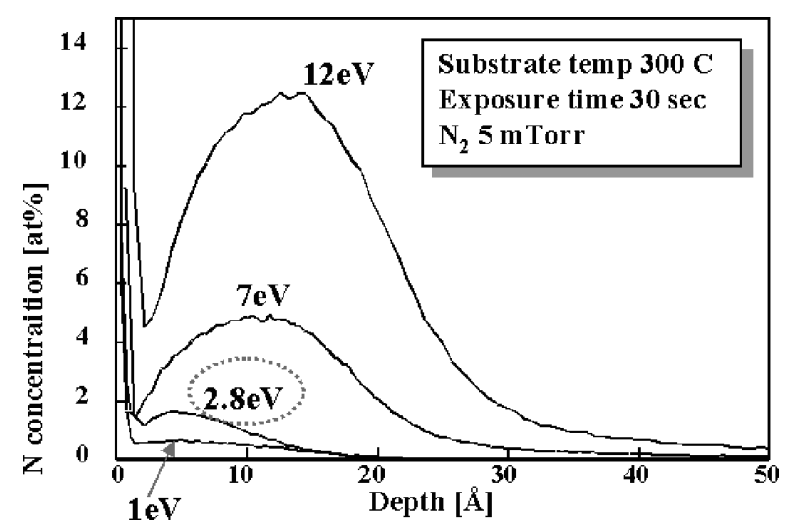

Fig. 10. $\mathrm{N}$ depth profile in thin $\mathrm{SiO}_{2}$ film as a function of beam energy using continuous wave neutral beam.
クエネルギーと $2 \mathrm{~nm}$ 厚シリコン酸化膜中での深さ方向 の $\mathrm{N}$ 濃度プロファイルを2 次イオン質量分析 (SIMS) にて分析した結果を示す。この結果より， $\mathrm{N}_{2}$ ビームエ ネルギーとして $3 \mathrm{eV}$ 以上ないとシリコン酸化膜中に窒 素が注入されないことがはじめてわかった。このことは プラズマ中の窒素ラジカルのような運動エネルギーを持 っていない活性種では窒化は促進されず，窒化には運動 エネルギーを持ったイオンや中性粒子が必要であること を示している。この窒化メカニズムをベースに Fig. 11 に示すパルス変調窒素分子ビームによる「間歇的な窒化」 方法によりシリコン酸化膜中の窒素濃度プロファイル制 御を試みた ${ }^{18)}$ 。パルス変調空素プラズマを利用すること で Fig. 11 に示すように注入されるビームエネルギーも 時間変調され，プラズマ OFF 中にはピークエネルギー が $2 \mathrm{eV}$ 以下のビームとなり, プラズマ ON 中にはピー クエネルギーが $10 \mathrm{eV}$ 以上のビームが注入される。つま り，プラズマ $\mathrm{ON}$ 中のみに窒素がシリコン酸化膜中に注 入されることになり, 間歇的な窒化が実現される。この 時, ON 時間を $10 \mu$ 秒まで短くするとシリコン酸化膜 中の窒素濃度プロファイルはピーク濃度を低下させずに 表面側に大幅にシフトすることがわかった。パルス変調 窒素ビーム注入により表面温度上昇や久陥生成が抑制さ れているために窒素の内部での拡散が抑制されているの ではないかと推測している18)。つまり, シリコン酸化膜

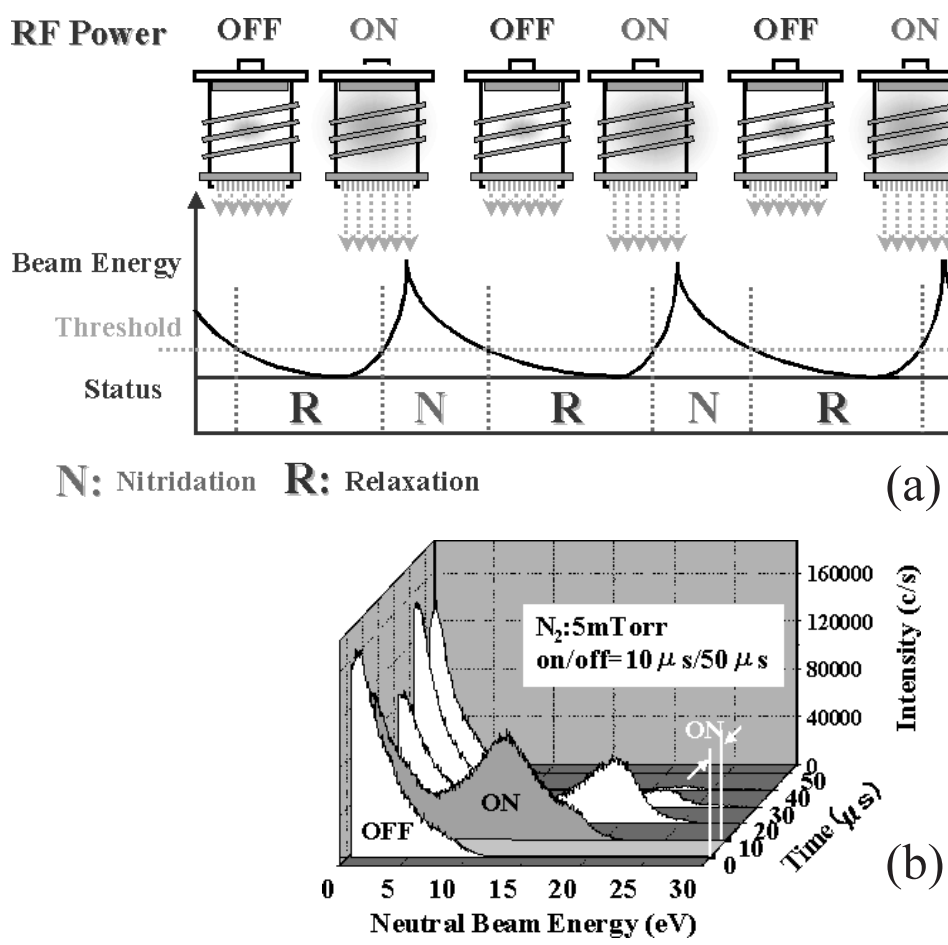

Fig. 11. (a) Pulsed $\mathrm{N}_{2}$ neutral beam injection method for control of $\mathrm{N}$ depth profile and (b) the actual $\mathrm{N}_{2}$ neutral beam energy. 
中での空素の拡散は表面温度上昇や欠陥生成により促進 されていることが予想され，その拡散は $\mu$ 秒オーダー の時定数で起きているものと想像できる。パルス変調窒 素中性粒子ビームでは低エネルギービーム照射時に表面 温度が低下し, 窒素の拡散が抑制されるものと考えられ る。結果として, Fig. 12 に示すようにパルス変調窒素 中性粒子ビームを用いることで窒素濃度プロファイル制 御が実現でき，信頼性も大幅に向上した。

\section{6. 量子ドットの形成}

現在のシリコン LSI は既に $100 \mathrm{~nm}$ 以下の世代に突入 し, 2020 年までにはムーアの法則の破綻やトランジス 夕動作の物理的限界に到達すると指摘されている。そう いうなかで量子効果を利用した新しい原理のデバイスの

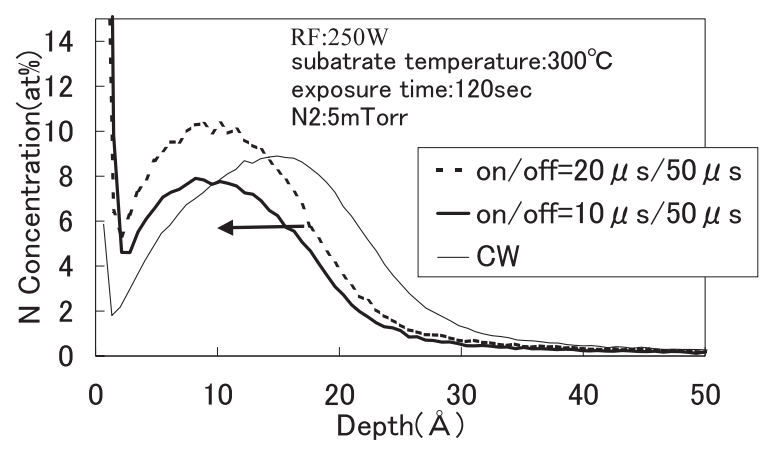

Fig. 12. $\mathrm{N}$ depth profile in thin $\mathrm{SiO}_{2}$ film using continuous wave and pulsed neutral beams.
開発が進められている。このデバイスにおいては如何に 精度良く損傷がなくナノ構造（ドット, ワイア）を形成 するかが大きな鍵になっている。ナノドットの形成には プラズマエッチングを用いたトップダウン方式と自己組 織化を利用したボトムアップ方式の両面で検討が行われ ている。しかし，プラズマを用いたトップダウン加工で はマスク材料との選択性やイオンなどの活性粒子の入射 方向性に問題があり, 現在までの結果では精々 $10 \mathrm{~nm}$ 程度の加工で限界であると考えられる。さらに, 量子サ イズのデバイスではプラズマからのイオン衝撃や紫外光 照射による結晶欠陥などダメージが大きな問題となって いる。一方, ボトムアップ方式では損傷などの問題は少 ないものの, ナノドット配列や構造の均一性などの問題 を抱えている。いずれにしても, 精度の良いナノ構造の 作製が今後のポイントとなる。

そこで, 私どもは低エネルギーダメージフリープロセ スが実現できる中性粒子ビームを用いたトップダウン加 工による $10 \mathrm{~nm}$ 以下のナノドットの形成を検討した。 数 $\mathrm{nm}$ ドットの加工マスクとしては, 山下らが提案して いるバイオナノプロセス ${ }^{19)}$ を用いた。Fig. 13 に示すよ うに生体超分子（蛋白質）であるフェリティンは直径 13 $\mathrm{nm}$ で内部が $7 \mathrm{~nm}$ の空洞となっている。この空洞内部 は負の電荷を帯びており, 鉄イオンが溶けた溶液中にフ エリティンを入れると鉄イオンがフェリティン内部に吸 収され鉄コアを作る。この鉄コアの直径は $7 \mathrm{~nm}$ である。 この鉄内包のフェリティンをシリコン基板上に 2 次元配

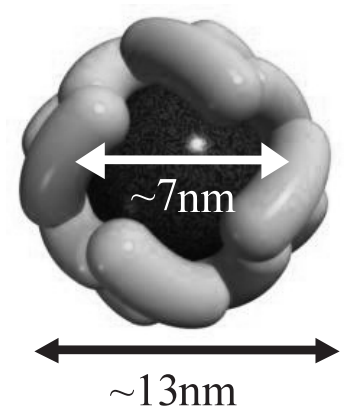

(a)
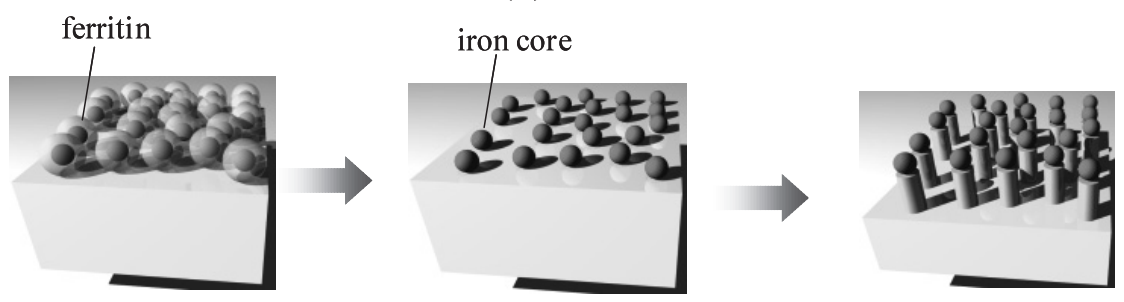

(b)

Fig. 13. (a) Structure of ferritin (protein) including iron core in the cavity and (b) Biao-nanoprocess for nanocolumn structure by using a ferritin iron-core mask. 
列した上で UV オゾン処理で蛋白質を除去し，鉄コアだ けを基板上に残してエッチングマスクとするプロセスで ある（Fig. 13）。ここで問題となるのは, フェリティン 内部で形成された脆弱な鉄のコアがエッチングマスクと して耐性があるかということである。すでに, 山下らに よってフルオロカーボンプラズマによるエッチングが試 みられているが，鉄がマスクとして十分な耐性がなく， また，プラズマエッチング中の電荷蓄積などで鉄が凝集 し, パターンがくっついてしまうなどの問題があり，十 分アスペクト比の高いパターンが実現できなかった。私 どもも独自に塩素プラズマでも検討を行ったが，Fig. 14 （a）に示すようにやはり鉄コアの耐性がなく，エッチン グ形状は垂直ではなく丸まってしまっている。而性がな い理由は，プラズマから照射される紫外線により鉄コア が破壊されることにあると考えられる。そこで塩素を主 体とした中性粒子ビームにより鉄コアをマスクにエッチ ングを試みた。Fig. 14（b）に塩素中性粒子ビームによ るエッチング形状を示す。鉄コアマスク通りに垂直な高 アスペクト異方性加工が実現できており，世界で初めて

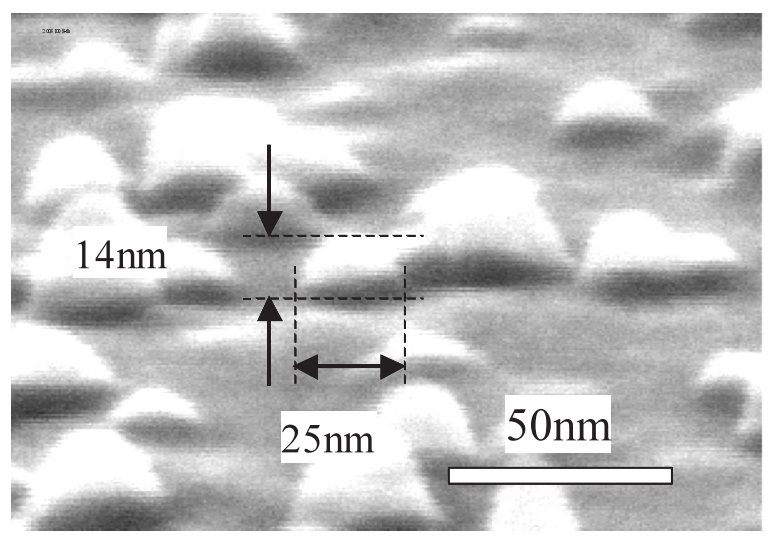

(a)

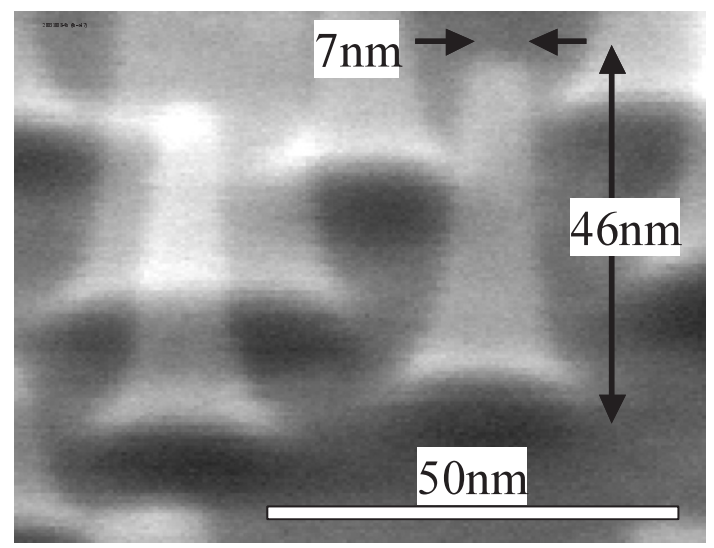

(b)

Fig. 14. Si etching profile with iron core mask using (a) conventional plasma and (b) neutral beam processes.
$7 \mathrm{~nm}$ 径シリコンドットの形成に成功した ${ }^{20)}$ 。XPS を用 いて塩素プラズマおよび塩素中性粒子ビームによる鉄コ アのエッチング速度を求め, シリコンとの選択性を算出 した。塩素プラズマでは選択比はほとんどないが，中性 粒子ビームでは 90 近い選択性が得られていることがわ かった。低エネルギーであると同時に紫外線などの放射 もない塩素・中性粒子ビームで初めて鉄コアに対して高 選択比が実現できたと考えられる。今後, バイオテクノ ロジーとナノテクノロジーの融合を考えると, 生体超分 子を破壊してしまう紫外光などの高エネルギー粒子を抑 制して必要な活性種だけを低エネルギーで照射できる中 性粒子ビームが極めて重要な技術となることが予想され る。このように，プラズマで発生する電荷や紫外線を制 御することで, 従来ではありえない究極のトップダウン 加工が実現できることを示した。今後はこのナノドット の結晶構造および結晶欠陥を解析した上で量子効果デバ イスなどの新デバイスへの展開を促進していきたいと思 う。

\section{7. ま め}

ナノオーダーの次世代半導体デバイスあるいは将来の ナノ構造を利用した新しいデバイスに必要不可欠なダメ ージフリー高精度加工・表面改質として主に中性粒子ビ ームプロセスを紹介した。プラズマプロセスでは電荷蓄 積や放射光の照射によるデバイス特性の劣化が大きな問 題になっており，それらの問題解決に中性粒子ビームが 極めて有効であり，且つ，原子層レベルの反応制御が実 現できることがわかった。今後は新材料のエッチングや 新しい機能薄膜材料堆積などの応用に展開し，新しい原 理のデバイスにおいても中性粒子ビームの有効性が実証 されていくことが期待される。

\section{文献}

1) T. Nozawa and T. Kinoshita: Jpn. J. Appl. Phys. 34, 2107 (1995).

2) T. Kinoshita, M. Hane and J.P. McVittee: J. Vac. Sci. Technol. B 14, 560 (1996).

3) H. Ootera: Jpn. J. Appl. Phys. 33, 6109 (1993).

4) H. Ohtake and S. Samukawa: Proc. 17 Dry Process Symp. (Institute of Electrical Engineering of Japan, Tokyo, 1995) p. 45.

5) K.P. Cheung and C.S. Pai: IEEE Device Lett. 16, 220 (1995).

6) J-P. Carrere, J-C. Oberlin and M. Haond: Proc. Int. Symp. on Plasma Process-Induced Damage (AVS, Monterey, 2000) p. 164.

7) T. Dao and W. Wu: Proc. Int. Symp. on Plasma Process- 
Induced Damage (AVS, Monterey, 1996) p. 54.

8) M. Joshi, J.P. McVittee and K. Sarawat: Proc. Int. Symp. on Plasma Process-Induced Damage (AVS, Monterey, 2000) p. 157.

9) C. Cismura, J.L. Shohet and J.P. McVittee: Proc. Int. Symp. on Plasma Process-Induced Damage (AVS, Monterey, 1999) p. 192.

10) J.R. Woodworth, M.G. Blain, R.L. Jarecki, T.W. Hamilton and B.P. Aragon: J. Vac. Sci. Technol. A 17, 3209 (1999).

11) T. Mizutani and S. Nishimatsu: J. Vac. Sci. Technol. A 6, 1417 (1988).

12) 鈴木敬三：応用物理 57, 1721 (1988).

13) F. Shimokawa: J. Vac. Sci. Technol. A 10, 1352 (1992).

14) 徳山 巍：“半導体ドライエッチング技術” (産業図
書, 1992).

15) S. Samukawa, K. Sakamoto and K. Ichiki: J. Vac. Sci. Technol. A 20, 1566 (2002).

16) S. Noda, H. Nishimori, T. Ida, T. Arikado, K. Ichiki and S. Samukawa: Extended Abstracts of International Conference on Solid State Devices and Materials (Tokyo, 2003) p. 472.

17) S. Samukawa, Y. Ishikawa, S. Kumagai and M. Okigawa: Jpn. J. Appl. Phys. 40, L 1346 (2001).

18) S. Samukawa, Y. Minemura and S. Fukuda: Jpn. J. Appl. Phys. 42, L 795 (2003).

19) 山下一郎：応用物理 71, 1014 (2002).

20) T. Kubota, T. Baba, H. Kawashima, Y. Uraoka, T. Fuyuki, I. Yamashita and S. Samukawa: Appl. Phys. Lett. 84, 9 (2004). 